\title{
PENERAPAN METODE TUTOR SEBAYA UNTUK MENINGKATKAN HASIL DAN MOTIVASI BELAJAR SISWA PADA MATERI TRIGONOMETRI KELAS XI MIPA 4 SMA NEGERI 1 AMBARAWA
}

\author{
Oktavian Rosa Abrianto ${ }^{1)}$ \\ Pendidikan Matematika, Universitas Kristen Satya Wacana ${ }^{1)}$ 202015074@student.uksw.edu ${ }^{1)}$, \\ Erlina Prihatnani $\left.{ }^{2}\right)$ \\ Pendidikan Matematika, Universitas Kristen Satya Wacana ${ }^{2)}$ \\ erlina.prihatnani@gmail.com ${ }^{2)}$
}

\begin{abstract}
The lack of optimal learning outcomes and motivation from learning that is not in accordance with the principles stated in the process standard forms the basis of classroom action research aimed at increasing mathematics learning outcomes and motivation for students of class XI MIPA 4 Ambarawa 1 SMA on trigonometry using peer tutoring methods. The model used in this study is Kurt Lewin with 4 steps, they are planning, action, observing, and reflection. The results showed that the average learning outcomes in cycle 1 were 73.55 with a percentage of completeness of $64 \%$ and up in cycle 2 with an average of 86.67 with a percentage of completeness of $85 \%$. As for aspects of learning motivation, students who entered the minimum good category amounted to $67 \%$ in cycle 1 and became $85 \%$ in cycle 2. Based on this, it can be concluded that the application of peer tutoring methods can improve learning outcomes and learning motivation in the trigonometry material of students of Grade XI MIPA 4 of Ambarawa Senior High School.
\end{abstract}

Keywords: peer tutor, learning outcomes, motivation to learn, trigonometry

\section{PENDAHULUAN}

Berdasarkan standar proses yang tercantum dalam Permendikbud Nomor 22 tahun 2016, salah satu prinsip pembelajaran adalah siapa saja adalah guru, siapa saja adalah peserta didik, dan di mana saja adalah kelas. Prinsip ini menandakan bahwa ruang belajar siswa tidak hanya dibatasi dinding ruang kelas dan tidak menutup kemungkinan bahwa seorang siswa dapat berperan seperti guru untuk membimbing teman yang lain dalam proses belajar. Selain prinsip tersebut, pembelajaran sekarang juga diharapkan dapat beralih dari guru sebagai satu-satunya sumber belajar menjadi berbasis aneka sumber. Prinsip ini menunjukkan jika dalam mengkonstruksi pengetahuan, siswa tidak hanya bergantung dari informasi yang diberikan guru, namun siswa juga dapat belajar dari lingkungan sekitar, buku-buku, sumber internet, bahkan belajar dari sesama teman.

Permasalahannya, belum semua pembelajaran telah menerapkan prinsip tersebut. Masih ditemukan proses pembelajaran matematika yang belum memenuhi prinsip-prinsip itu. Pembelajaran masih berpusat pada guru dengan proses pembelajaran yang monoton, yaitu transfer knowledge oleh guru yang berupa penyampaian materi, penyampaian contoh soal yang dilanjutkan latihan soal. Pembelajaran seperti ini juga terjadi di SMA Negeri 1 Ambarawa kelas XI MIPA 4. Observasi yang dilakukan selama magang 2 dari bulan Januari sampai April, tampak bahwa dalam mengajarkan materi guru menggunakan metode ceramah dan latihan soal. Setelah guru menjelaskan materi dan memberi contoh 
soal, guru kemudian memberikan latihan soal. Ketika pengerjaan latihan soal siswa diberi kesempatan untuk berdiskusi. Namun, sayangnya tidak semua siswa antusias untuk mengerjakannya, bahkan tak jarang siswa yang tidak melakukan proses membaca soal dan langsung menyalin dari jawaban teman lainnya. Pada tahap ini, guru sudah membiasakan untuk memberi kesempatan kepada siswa untuk mengerjakan di papan tulis. Namun tidak semuanya dibarengi dengan proses penjelasan langkah pengerjaannya. Penjelasan dilakukan hanya jika ada teman yang bertanya. Jadi sebenarnya pada tahap latihan soal ini, telah terjadi proses belajar dari teman sebayanya. Sayangnya pelaksanaannya belum optimal, dominasi guru masih tampak serta alokasi waktu yang relatif singkat (hanya dalam latihan soal).

Selain itu, ditemukan fakta lain. Siswa tampak tidak termotivasi dalam belajar terlebih saat proses penjelasan guru. Hal ini tampak dari beberapa siswa yang asyik ngobrol dan hanya sedikit siswa yang mencatat. Ketika guru menjelaskan, hanya siswasiswa tertentu yang bertanya jika terdapat materi yang kurang dipahami, sedangkan siswa yang lain tidak bertanya meskipun mereka tidak tahu. Tidak termotivasinya siswa juga tampak dari beberapa siswa ijin ke toilet dalam waktu yang relatif lama. Selain itu, beberapa siswa juga mengerjakan tugas mata pelajaran lain ketika pelajaran matematika berlangsung. Hal tersebut pula dibenarkan oleh guru matematika yang mengajar di kelas ini. Beliau mengatakan bahwa sejak Ujian Nasional (UN) bukan penentu kelulusan, motivasi siswa dalam belajar matematika tidak sekuat siswa-siswa ketika UN masih menjadi penentu kelulusan.

Menurut Hanafiah \& Suhana (2009: 26), motivasi belajar adalah kekuatan (power motivation), daya pendorong (driving force), atau alat pembangun kesediaan dan keinginan yang kuat dalam diri siswa untuk belajar secara aktif, kreatif, efektif, inovatif, dan menyenangkan dalam rangka perubahan perilaku, baik dalam aspek kognitif, afektif, maupun psikomotor. Lebih lanjut, Sardiman (Hendriana, 2017:170) mengemukakan bahwa salah satu bentuk dan cara untuk menumbuhkan motivasi belajar adalah menciptakan suasana bersaing yang sehat yang memotivasi siswa untuk aktif selama pembelajaran. Pembelajaran sebaiknya diisi dengan melakukan kegiatan, berkreasi, menciptakan sesuatu, dan menyelesaikan suatu masalah. Membuat siswa menjadi pasif di kelas dapat menurunkan motivasi belajarnya. Siswa sebaiknya bukan hanya sebagai objek, namun juga merupakan subjek yang aktif dalam pembelajaran yang tidak hanya mengandalkan peranan guru namun juga aktif dalam mencari dari sumber belajar berupa buku, bahan ajar, maupun dari teman sebayanya. Pengoptimalan peran siswa dalam belajar diharapkan dapat menumbuhkan motivasi belajar siswa. Salah satu metode pembelajaran yang mungkin digunakan untuk menciptakan kondisi tersebut adalah metode tutor sebaya.

Sabbaruddin (2009) mengatakan bahwa metode tutor sebaya ialah pemanfaatan siswa yang mempunyai keistimewaan, kepandaian dan kecakapan di dalam kelas untuk membantu memberi penjelasan, bimbingan dan arahan kepada siswa yang kepandaiannya agak kurang atau lambat dalam menerima pelajaran yang usianya hampir sama atau sekelas. Adapun tutor sebaya adalah seseorang atau beberapa peserta didik yang dipilih oleh guru sebagai tutor atau pembantu guru di dalam melaksanakan bimbingan terhadap 
kawan sekelas Arikunto (1986 : 77). Metode Tutor sebaya dapat diterapkan di sekolah yang didalamnya terdapat siswa yang memiliki kepandaian dan rasa percaya diri untuk dapat membantu menjelaskan kepada siswa lain. Hal ini bertujuan agar siswa yang merasa malu atau minder bertanya kepada guru dapat bertanya dengan teman sebayanya. Hal ini sejalan dengan yang dikemukakan Septiana (2013) dalam penelitiannya, yang mengatakan bahwa metode tutor sebaya membuat siswa merasa nyaman bertanya tanpa ada rasa minder atau malu. Selain itu bagi siswa yang menjadi tutor bisa dilatih kemampuan berbicara di depan kelas dalam hal ini adalah melatih siswa mengajar temannya, agar rasa malu dalam dirinya cenderung berkurang, sehingga materi yang akan disampaikan dapat dengan jelas diterima oleh siswa.

Penerapan metode tutor sebaya dapat memberi dampak positif terhadap hasil belajar. Hal itulah yang ditemukan oleh Septiana (2013) dalam penelitiannya terhadap siswa SMP Kristen 2 Salatiga pada materi bangun datar. Hal yang sama juga ditemukan oleh Prasojo (2016) dalam penelitiannya pada materi Trigonometri bagi siswa SMA Negeri 1 Kudus.

Selain berdampak positif terhadap hasil belajar, beberapa penelitian juga menyimpulkan bahwa tutor sebaya juga dapat memberikan dampak positif terhadap motivasi belajar. Contohnya, penelitian Ritaningsih (2017) pada pelajaran IPA, penelitian Khasanah (2013) pada mata pelajaran IPS dan penelitian Mawarni (2015) pada mata pelajaran Kimia.

Belum sesuainya pembelajaran dengan prinsip belajaran dari berbagai sumber dan siapa saja adalah guru, siapa saja adalah siswa, dan dimana saja adalah kelas serta dibarengi dengan pencapaian hasil belajar dan motivasi belajar yang belum sesuai harapan menjadi dasar dilakukannya penelitian tindakan kelas (PTK). Adanya teori dan berbagai penelitian tentang tutor sebaya menjadi dasar pemilihan metode tutor sebaya menjadi salah satu upaya untuk memperbaiki proses belajar guna meningkatkan hasil belajar dan motivasi belajar.

Penerapan metode tutor sebaya dalam penelitian ini diharapkan dapat mengoptimalkan peran siswa sebagai subjek pembelajar dan dapat melatih kepercayaan diri sekaligus kemampuan komunikasi siswa yang terpilih sebagai tutor. Selain itu, keberadaan tutor diharapkan mampu memberikan stimulus kepada siswa lainnya untuk dapat melatih diri hingga dapat terpilih menjadi tutor. Penerapan tutor sebaya diharapkan juga dapat meningkatkan interaksi antar siswa sehingga pembelajaran dapat lebih aktif. Selain itu, diharapkan penelitian ini dapat memberi gambaran kepada guru tentang penerapan tutor sebaya pada materi trigonometri sekaligus dapat menjadi salah satu sumber referensi guru untuk merancang dan menerapkan metode tutor sebaya dalam pembelajaran.

\section{METODE PENELITIAN}

Jenis penelitian ini adalah Penelitian Tindakan Kelas (PTK). Menurut Tampubolon (2013 : 19), penelitian tindakan kelas merupakan penelitian yang 
dilaksanakan oleh pendidik/ calon pendidik di dalam kelasnya sendiri secara kolaboratif/ partisipatif untuk memperbaiki kinerja pendidik yang berkaitan dengan kualitas proses pembelajaran, dan meningkatkan hasil belajar siswa, baik dari aspek akademik maupun nonakademik, melalui tindakan reflektif dalam bentuk siklus (daur ulang). Model atau desain penelitian yang diterapkan dalam penelitian ini adalah model Kurt Lewin. Model Kurt Lewin didesain dalam bentuk satu siklus yang terdiri dari empat tahapan yaitu (1) perencanaan tindakan (planning), (2) pelaksanaan tindakan (action), (3) observasi/pengamatan (observing), dan (4) refleksi (reflection).

Penelitian ini dilakukan di kelas XI MIPA 4 SMA Negeri 1 Ambarawa yang beralamat di jalan Yos Sudarso No 46, Kupang, Ambarawa, Jawa Tengah 50612. Subjek pada penelitian ini adalah 33 siswa yang terdiri dari 7 siswa laki-laki serta 26 perempuan. Penelitian dilakukan pada bulan Januari hingga Desember 2018. Metode tutor sebaya diterapkan dalam pembelajaran matematika sejak tanggal 26 Juli 2018 sampai tanggal 22 November 2018. Penelitian ini dilaksanakan dalam siklus yang berhenti apabila; (1) ratarata nilai hasil belajar siswa mencapai KKM yang ditetapkan yaitu 72, (2) ketuntasan kelas mencapai minimal 75\%, (3) 75\% siswa memiliki tingkat motivasi dalam kategori minimal baik.

\section{HASIL PENELITIAN DAN PEMBAHASAN}

\section{Pra Siklus}

Hasil belajar siswa sebelumnya rata-rata hanya mencapai 46,21 jauh dari KKM yang ditetapkan yaitu 72. Selain itu, sebelum dilaksanakan proses remedial persentase siswa yang tuntas hanya 6\% sedangkan 94\% lainnya tidak mencapai ketuntasan. Sebagian besar siswa tampak tidak memiliki motivasi dalam belajar matematika. Hal tersebut dapat dilihat dari hasil observasi proses pembelajaran matematika dimana sedikit siswa yang fokus serta sebagian siswa tampak tidak serius dalam belajar matematika. Ketidakseriusan itu nampak dari tidak sungguh-sungguhnya siswa dalam mengerjakan tugas (banyak yang mencontek dan tidak selesai dalam mengerjakan tugas); dan tidak jarang justru membuat kegaduhan dalam kelas serta tidak memperhatikan guru. Selain itu proses belajar yang terjadi adalah penjelasan guru, pemberian contoh soal, pemberian latihan soal, dan pelaksanaan ulangan harian.

\section{Siklus 1}

\section{Perencanaan Tindakan}

Penelitian ini menggunakan metode tutor sebaya. Berdasarkan hasil pengamatan pembelajaran di kelas dan rekapitulasi nilai kelas XI MIPA 4 serta diskusi dengan guru matematika maka terpilih 2 orang sebagi tutor untuk memberikan penjelasan terhadap teman satu kelas. Selanjutnya guru memberi arahan terkait materi serta penjelasan peran/ tugas tutor kepada keduanya. Proses ini dilaksanakan satu kali sebelum pelaksanaan penelitian. Pada tahap ini guru juga mempersiapkan semua perangkat pembelajaran, diantaranya lembar kerja siswa tentang persamaan trigonometri, instrumen angket motivasi belajar, serta RPP. 


\section{Pelaksanaan Tindakan}

Dalam penelitian ini peneliti berperan sebagai guru, sedangkan guru matematika kelas XI MIPA 4 bertindak sebagai observer. Pelaksanaan tindakan pada siklus 1 terbagi menjadi 5 pertemuan dimana pada setiap pertemuan terbagi menjadi 3 kegiatan yaitu kegiatan awal, inti, dan penutup.

a. Kegiatan Awal

Kegiatan pembelajaran dalam setiap siklusnya mengacu pada Permendiknas nomor 22 tahun 2016 yaitu diawali dengan menyiapkan peserta didik secara psikis dan fisik, memberikan manfaat kontekstual, memberikan pertanyaan yang berhubungan dengan materi sebelumnya, menyampaikan tujuan pembelajaran serta menyampaikan cangkupan materi dan kegiatan yang akan dilakukan. Setiap pertemuan, peneliti mempersiapkan peserta didik secara psikis berupa penyampaian kata-kata motivasi sebagai sarana untuk menumbuhkan motivasi siswa dalam belajar. Peneliti juga selalu menginformasikan manfaat dari materi trigonometri.

Tujuan pembelajaran pada pertemuan pertama, kedua sampai pertemuan kelima secara berturut-turut yaitu memahami konsep dasar persamaan trigonometri serta memahami hubungan grafik fungsi trigonomertri dengan persamaan trigonometri, menentukan nilai $x$ pada persamaan trigonometri sinus serta cosinus, menentukan nilai $x$ pada persamaan trigonometri tangen, dan menyelesaikan permasalahan pada persamaan trigonometri berbentuk a $\cos x+\mathrm{b} \sin x=c$, serta pada pertemuan kelima melakukan evaluasi dengan pemberian posttest akhir siklus 1 .

b. Kegiatan Inti

Proses pembelajaran selalu menggunakan lembar kerja pada setiap pertemuannya. Kegiatan pembelajaran pada pertemuan pertama sampai pertemuan kelima menggunakan metode tutor sebaya untuk menyelesaikan masalah yang berkaitan dengan persamaan trigonometri. Siswa AAU sebagai tutor menjelaskan tentang persamaan trigonometri sinus dan cosinus. Adapun siswa FLZ menjelaskan tentang persamaan trigonometri tangen serta persamaan trigonometri berbentuk a $\cos x+\mathrm{b} \sin x=c$. Tidak hanya menjelaskan saja, namun siswa AAU dan FLZ juga memimpin siswa lainya untuk mengerjakan latihan soal. Ketika pengerjaan latihan soal tidak hanya tutor yang mengerjakan namun siswa lain juga diberi kesempatan untuk mengerjakan soal yang dibimbing oleh kedua tutor.

c. Kegiatan Penutup

Pada setiap pertemuan, terdapat 4 (empat) kegiatan yang dilakukan secara berulang-ulang setiap pertemuannya. Keempat kegiatan tersebut adalah refleksi atas aktivitas yang sudah dilakukan dan pemahaman akan materi yang telah dipelajari, pemberian umpan balik, rencana tindak lanjut, dan memberikan informasi untuk pertemuan selanjutnya. 


\section{Pengamatan}

Setiap proses pembelajaran dilakukan pengamatan dengan lembar observasi. Rekapitulasi hasil observasi dapat dilihat pada Tabel 1. Berdasarkan Tabel 1 tampak bahwa kesesuaian pelaksanaan pembelajaran dengan standar proses Kurikulum 2013, kesesuaian pembelajaran dengan metode tutor sebaya, kemampuan guru dalam pengelolaan kelas, dan kemampuan guru dalam penguasaan materi dalam kategori sangat baik. Namun masih ada beberapa aspek yang perlu diperbaiki dan ditingkatkan. Contohnya, masih dominannya peran guru dalam proses pembelajaran dikarenakan belum terbiasanya siswa yang terpilih sebagai tutor.

\section{Tabel 1 Hasil Rekapitulasi Lembar Observasi Guru Siklus 1}

\begin{tabular}{clcc} 
No & \multicolumn{1}{c}{ Aspek yang diamati } & Persentase & Kategori \\
\hline 1. & $\begin{array}{l}\text { Kesesuaian pelaksanaan pembelajaran dengan standar } \\
\text { proses Kurikulum 2013 }\end{array}$ & $89,81 \%$ & Sangat Baik \\
\hline 2. & Kesesuaian pembelajaran dengan metode tutor sebaya. & $89,58 \%$ & Sangat Baik \\
\hline 3. & Kemampuan guru dalam pengelolaan kelas. & $93,18 \%$ & Sangat Baik \\
\hline 4. & Kemampuan guru dalam penguasaan materi. & $93,75 \%$ & Sangat Baik \\
\hline
\end{tabular}

Adapun untuk perolehan hasil belajar pada siklus 1 dapat dilihat pada Gambar 1 dan Tabel 2.

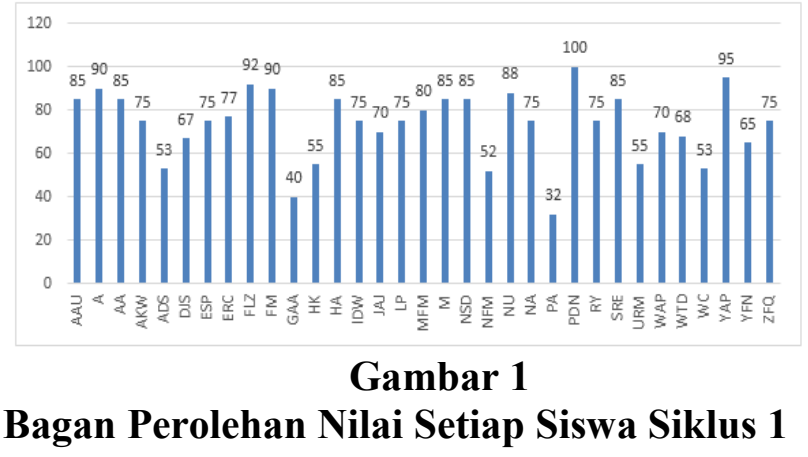

\begin{tabular}{|c|c|c|c|}
\hline \multicolumn{4}{|c|}{$\begin{array}{c}\text { Tabel } 2 \\
\text { Hasil Belajar Siklus } 1\end{array}$} \\
\hline \multirow{3}{*}{ Nilai } & $\begin{array}{c}\text { Maksima } \\
1\end{array}$ & \multicolumn{2}{|c|}{100} \\
\hline & Minimal & \multicolumn{2}{|c|}{32} \\
\hline & Rata-rata & \multicolumn{2}{|c|}{73,6} \\
\hline \multirow{2}{*}{$\begin{array}{c}\text { Tingkat } \\
\text { Ketuntasa } \\
n\end{array}$} & $\begin{array}{c}\text { Siswa } \\
\text { yang } \\
\text { Tuntas }\end{array}$ & $\begin{array}{l}2 \\
1\end{array}$ & $\begin{array}{l}64 \\
\%\end{array}$ \\
\hline & $\begin{array}{l}\text { Siswa } \\
\text { yang } \\
\text { belum } \\
\text { Tuntas }\end{array}$ & $\begin{array}{l}1 \\
2\end{array}$ & $\begin{array}{l}36 \\
\%\end{array}$ \\
\hline
\end{tabular}

Pelaksanaan pembelajaran pada Siklus 1 menggunakan metode tutor sebaya telah menghasilkan rata-rata 73,6. Hasil tersebut sudah diatas KKM yitu 72. Namun ketuntasan kelas baru mencapai $64 \%$. Adapun rekapitulasi hasil pengisian angket dapat dilihat pada Tabel 3. Berdasarkan Tabel 3, tampak bahwa persentase siswa dengan motivasi belajar minimal kategori baik mencapai $67 \%$ hasil tersebut belum mencapai batas indikator keberhasilan yaitu $75 \%$. 
Tabel 3 Motivasi Belajar Siklus 1

\begin{tabular}{|c|c|c|}
\hline Kriteria & Jumlah Siswa & Persentase \\
\hline Sangat Baik & 4 & $12 \%$ \\
\hline Baik & 18 & $55 \%$ \\
\hline Cukup & 11 & $33 \%$ \\
\hline Kurang & 0 & $0 \%$ \\
\hline
\end{tabular}

\section{Refleksi}

Pelaksanaan pembelajaran pada Siklus 1 diakhiri dengan kegiatan refleksi dari seluruh kegiatan yang dilaksanakan pada siklus 1 . Kelebihan pada Siklus 1 yaitu siswa menikmati pembelajaran yang disampaikan oleh teman sebayanya tanpa ada rasa sungkan kepada teman sebayanya, ini berarti bahwa selama proses pembelajaran siswa menjadi lebih termotivasi untuk aktif dalam proses pembelajaran. Hal tersebut pula yang mengakibatkan motivasi belajar siswa meningkat karena lebih terlibat dalam proses pembelajaran. Sementara kekurangan yang terdapat pada siklus 1 yaitu kedua tutor masih kewalahan dalam pelaksanaan pembelajaran sehingga kedua tutor merasa butuh tambahan tutor lagi untuk memaksimalkan proses tutoring.

\section{Siklus 2}

\section{Perencanaan Tindakan}

Perencanaan tindakan pada siklus 2 dilaksanakan dengan menyusun pembelajaran dengan evaluasi pada siklus 1. Strategi yang dipertahankan pada siklus 2 adalah penggunaan LK serta menggunakan metode tutor sebaya,. Pada siklus 2 guru memadukan LK penggunaan power point, hal tersebut digunakan supaya setiap pertemuan pada siklus 2 dapat lebih baik. Peneliti juga menunjuk satu lagi tutor untuk membantu pelaksanaan tindakan pembelajaran dalam hal ini ditujukan untuk memperbaiki kekurangan yang terdapat pada siklus 1 . Peneliti merujuk dari hasil posttest 1 serta diskusi dengan guru dan siswa berkaitan dengan penunjukkan tutor. Tutor ketiga yang terpilih adalah NA.

\section{Pelaksanaan Tindakan}

Seperti halnya pada siklus 1, tahap pelaksanaan dilakukan setelah tahap perencanaan tindakan. Pelaksanaan tindakan pada siklus 2 terbagi menjadi 6 pertemuan, pada setiap pertemuan terdapat 3 kegiatan seperti siklus 1 yaitu kegiatan awal, inti, serta penutup.

\section{a. Kegiatan Awal}

Kegiatan awal pada siklus 2 seperti siklus 1 yaitu terdiri dari 5 langkah dari mempersiapkan peserta didik secara psikis dan fisik sampai menyampaikan cakupan dan langkah kegiatan. Setiap pertemuan pada siklus 2 guru menyampaikan kata-kata motivasi yang beraneka ragam guna menumbuhkan dan meningkatkan motivasi siswa, contoh motivasi yang diberikan adalah "Tuhan tidak menuntut kita untuk sukses, yang dituntut adalah kita terus berjuang tanpa henti sampai titik darah penghabisan." Selain memotivasi siswa melalui kata-kata, motivasi pada setiap pertemuan dilakukan guru dengan memberikan acuan berupa reward yang akan diberikan kepada tiga siswa yang mendapat nilai tertinggi. Pada pertemuan keenam guru mengingatkan mengenai reward yang didapatkan sebagai bentuk motivasi sebelum mengerjakan posttest 2 . 
Selain pemberian motivasi yang membedakan setiap pertemuannya adalah tujuan pembelajaran. Tujuan pembelajaran pada pertemuan pertama adalah memahami konsep dasar serta membuktikan rumus jumlah dan selisih dua sudut untuk sinus, pada pertemuan kedua membuktikan rumus serta menentukan suatu nilai berkaitan dengan jumlah dan selisih dua sudut untuk cosinus dan tangen. Tujuan pada pertemuan ketiga yaitu membuktikan dan menentukan suatu nilai berkaitan dengan sudut rangkap. Kemudian untuk pertemuan keempat yaitu membuktikan rumus serta menentukan suatu nilai berkaitan dengan perkalian trigonometri sinus dan cosinus. Pada pertemuan kelima siswa membuktikan serta menenentukan rumus penjumlahan dan pengurangan untuk sinus dan cosinus. Pertemuan keenam dilaksanakan evaluasi dengan pemberian posttest akhir siklus 1.

\section{b. Kegiatan Inti}

Strategi yang digunakan oleh guru pada siklus 2 sama dengan strategi yang digunakan pada siklus 1 yaitu menerapkan metode tutor sebaya yang didukung dengan lembar kerja serta power point. Pada setiap kegiatan guru juga memberikan apresiasi dan kata-kata positif kepada peserta didik. Sementara untuk pelaksanaan tutoringnya, ketiga tutor saling bekerja sama dalam proses pembelajaran. Siswa AAU menjelaskan serta memandu siswa tentang bagaimana membuktikan rumus jumlah dan selisih dua sudut untuk sinus, cosinus, serta tangen. Adapun siswa FLZ menjelaskan serta memandu siswa tentang bagaimana membuktikan rumus sudut rangkap, perkalian trigonometri sinus dan cosinus. Sementara siswa NA menjelaskan serta memandu siswa tentang bagaimana membuktikan serta menentukan rumus penjumlahan dan pengurangan untuk sinus dan cosinus. Selain itu, ketiga tutor juga memberikan kesempatan untuk siswa lain untuk mengerjakan latihan soal.

\section{c. Kegiatan Penutup}

Seperti pada siklus 1 , siklus 2 juga terdapat 4 (empat) kegiatan yang dilakukan secara berulang-ulang setiap pertemuannya. Kegiatan tersebut yaitu melakukan refleksi mengenai aktivitas yang sudah dilakukan dan materi yang telah dipelajari, pemberian umpan balik, rencana tindak lanjut, dan memberikan informasi untuk pertemuan selanjutnya.

\section{Pengamatan}

Rekapitulasi hasil observasi aktivitas guru dapat dilihat pada Tabel 4. Berdasarkan tabel 4 tampak bahwa kesesuaian pelaksanaan pembelajaran dengan standar proses Kurikulum 2013, kesesuaian pembelajaran dengan metode tutor sebaya, dan kemampuan guru dalam pengelolaan kelas mengalami peningkatan daripada siklus 1, bahkan kemampuan guru dalam penguasaan materi mendapat point maksimal yaitu 100\%. 
Tabel 4 Hasil Rekapitulasi Lembar Observasi Aktivitas Guru Siklus 2

\begin{tabular}{clcc}
\hline No & \multicolumn{1}{c}{ Aspek yang diamati } & Persentase & Kategori \\
\hline 1. & $\begin{array}{l}\text { Kesesuaian pelaksanaan pembelajaran dengan standar } \\
\text { proses Kurikulum 2013 }\end{array}$ & $96,23 \%$ & Sangat Baik \\
\hline 2. & Kesesuaian pembelajaran dengan metode tutor sebaya. & $93,75 \%$ & Sangat Baik \\
\hline 3. & Kemampuan guru dalam pengelolaan kelas. & $97,73 \%$ & Sangat Baik \\
\hline 4. & Kemampuan guru dalam penguasaan materi. & $100 \%$ & Sangat Baik \\
\hline
\end{tabular}

Selain observasi terhadap pelaksanaan pembelajaran yang dilaksanakan guru pada siklus 2, Adapun untuk perolehan hasil belajar pada siklus 2 dapat dilihat pada Gambar 2 dan Tabel 5.

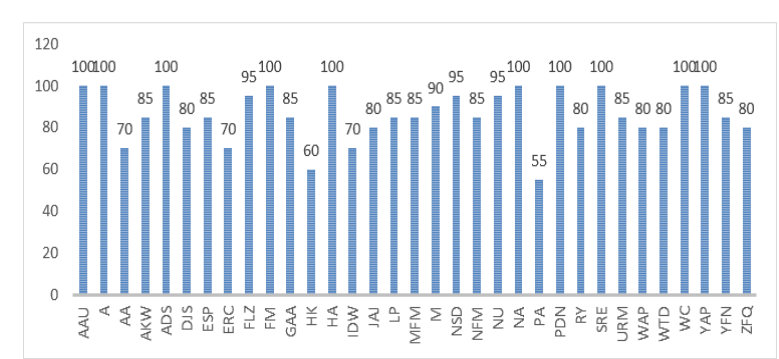

Gambar 2

\section{Bagan Perolehan Nilai Setiap Siswa Siklus}

\section{2}

Setelah melaksanakan pembelajaran pada Siklus 2 menggunakan metode tutor sebaya, rata-rata hasil belajar siswa telah mencapai 86,7 . Sementara ketuntasan kelas telah mencapai $85 \%$. Hasil tersebut telah mencapai indikator untuk aspek ketuntasan kelas yaitu 75\%. Rekapitulasi hasil pengisian angket di akhir pembelajaran siklus 2 dapat dilihat pada Tabel 6. Pada Tabel 6, tampak bahwa yang masuk kategori sangat baik sebesar 3\% ditambah kategori baik 82\%. Jadi total siswa dalam kategori minimal baik sebesar $85 \%$ dan telah memenuhi indikator keberhasilan untuk aspek motivasi belajar yaitu $75 \%$.

Tabel 6 Motivasi Belajar Siklus 2

\begin{tabular}{|c|c|c|}
\hline Kriteria & Jumlah Siswa & Persentase \\
\hline Sangat Baik & 1 & $3 \%$ \\
\hline Baik & 27 & $82 \%$ \\
\hline Cukup & 5 & $15 \%$ \\
\hline Kurang & 0 & $0 \%$ \\
\hline
\end{tabular}

\section{Refleksi}

Setelah selesai melaksanakan kegiatan pembelajaran pada siklus 2, diketahui hasil belajar siswa meningkat. Hal ini dikarenakan tutor sudah terbiasa melaksanakan proses tutoring sehingga pembelajaran menjadi lebih optimal. Adapun untuk siswa lainnya, mereka tampak lebih enjoy dan aktif untuk bertanya jika tidak mengerti karena yang menjelaskan adalah teman sebayanya. Sehingga hasil belajar menjadi optimal. Sementara untuk motivasi belajar siswa juga mengalami peningkatan. Hal tersebut karena siswa lebih aktif terlibat dalam pembelajaran sehingga motivasi belajar mereka juga meningkat. 


\section{Deskripsi Antar Siklus}

Hasil belajar dari kedua tindakan tersebut mengalami peningkatan yang cukup signifikan apabila dibandingkan dari siklus 1 ke siklus 2. Berdasarkan hasil tersebut tampak bahwa persentase hasil belajar dan motivasi belajar pada siklus 1 berturut-turut $64 \%$ dan $67 \%$ pencapaian tersebut belum memenuhi indikator keberhasilan. Hasil pada siklus 2, persentase hasil belajar dan motivasi belajar siswa pada siklus 2 yaitu $85 \%$ pencapaian ini telah mencapai indikator keberhasilan. Berdasarkan pada Tabel 7 dapat dilihat bahwa nilai rata-rata kelas dari siklus 1 ke siklus 2 mengalami peningkatan. Adapun perbandingan hasil belajar dan motivasi belajar siklus 1 dengan siklus 2 dapat dilihat pada Gambar 3. Berdasarkan hasil tersebut, maka penelitian berakhir pada siklus 2 .

Tabel 7 Perbandingan Hasil Belajar Siklus 1 dan Siklus 2
\begin{tabular}{|l|l|l|l|l|}
\hline Siklus & $\begin{array}{l}\text { Jumlah } \\
\text { Siswa }\end{array}$ & $\begin{array}{l}\text { Nilai } \\
\text { Tertinggi }\end{array}$ & $\begin{array}{l}\text { Nilai } \\
\text { Terendah }\end{array}$ & $\begin{array}{l}\text { Nilai Rata- } \\
\text { Rata Kelas }\end{array}$ \\
\hline Siklus 1 & 33 & 100 & 32 & 73,55 \\
\hline Siklus 2 & 33 & 100 & 55 & 86,67 \\
\hline
\end{tabular}

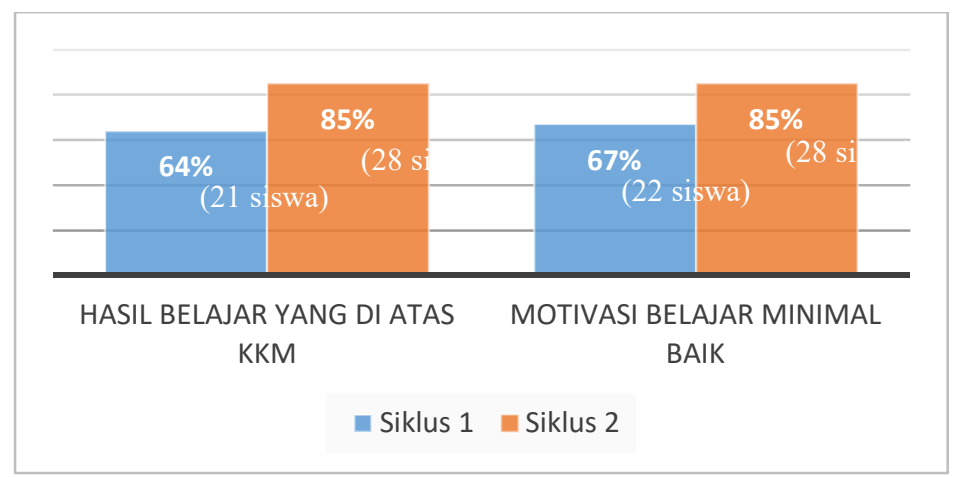

\section{Gambar 3 Perbandingan Hasil Belajar dan Motivasi Belajar Siswa Siklus 1 dan} Siklus 2

\section{PEMBAHASAN}

Terdapat permasalahan pada kondisi pra siklus, yaitu proses pembelajaran yang tidak sesuai dengan salah satu prinsip pembelajaran pada Permendikbud Nomor 22 tahun 2016 yang menerapkan pembelajaran siapa saja adalah guru, siapa saja adalah peserta didik, dan di mana saja adalah kelas. Proses pembelajaran masih berpusat kepada guru, guru sebagai satu-satunya sumber belajar. Proses pembelajaran tersebut tidak menghasilkan hasil belajar dan motivasi belajar yang diharapkan. Hasil observasi menunjukkan hanya sedikit siswa yang fokus dan hanya sebagian siswa tampak tidak serius dalam belajar matematika serta masih banyak siswa yang merasa malu atau minder untuk bertanya pada guru apabila masih ada yang kurang jelas. Berdasarkan hasil pra siklus menunjukkan rata-rata hasil belajar kelas XI MIPA 4 yaitu 46,21 dengan ketuntasan yang dicapai hanya $6 \%$ sehingga belum mencapai indikator keberhasilan yang sudah ditetapkan yaitu 72 dan juga ketuntasan kelas minimal 75\%. Mengacu pada 
permasalahan tersebut, maka dilakukan pembelajaran dengan menerapkan metode tutor sebaya.

Berdasarkan hasil pelaksanaan kegiatan pembelajaran pada siklus 1. Diketahui bahwa hasil belajar dan motivasi belajar sudah jauh lebih baik daripada hasil pra siklus. Salah satu faktor keberhasilan pembelajaran adalah kesiapan penyusunan perangkat pembelajaran yang sesuai serta guru yang mempersiapkan LK dengan pertanyaanpertanyaan yang dapat mempermudah proses konstruksi pengetahuan sehingga mempermudah tutor untuk melakukan perannya. Selain itu, tutor dan siswa dapat berinteraksi dengan baik karena yang menjelaskan adalah temannya. Kegiatan pembelajaran tersebut dapat terlaksana dengan baik karena adanya persiapan yang matang yang dapat dilihat dari hasil observasi siklus 1 yang mencangkup perencanaan tindakan, pelaksanaan tindakan, pengamatan, dan refleksi. Pada Tabel 1 terlihat bahwa pelaksanaan pembelajaran yang meliputi kegiatan atau tindakan guru dalam kegiatan awal, inti dan penutup pada pembelajaran sudah dirancang dan dilaksanakan dengan sangat baik. Pembelajaran terlaksana sesuai dengan metode tutor sebaya serta terdapat pengelolaan kelas yang sangat baik hal ini berarti bahwa proses pembelajaran berlangsung kondusif. Penguasaan materi oleh guru juga termasuk dalam kategori sangat baik. Hal ini dikarenakan guru dapat menyampaikan konsep pada permasalahan trigonometri dalam kehidupan sehari-hari. Meskipun hasil belajar sudah meningkat, namun hasil tersebut belum mencapai indikator keberhasilan. Belum tercapainya indikator pada siklus 1 dikarenakan proses tutoring yang belum optimal, kedua tutor membutuhkan tambahan tutor lagi guna mengoptimalkan proses tutoring. Oleh karena itu pada siklus 2 peneliti menunjuk satu lagi tutor untuk membantu pelaksanaan tindakan pembelajaran.

Hasil belajar dan motivasi belajar pada siklus 2 telah mencapai indikator keberhasilan. Berdasarkan hasil tersebut tampak bahwa indikator keberhasilan rata-rata kelas mencapai 86,7 . Persentase ketuntasan kelas mencapai $85 \%$, serta motivasi belajar minimal pada kategori baik sebesar $85 \%$, maka indikator keberhasilan telah dipenuhi. Hal tersebut dikarenakan pada siklus 2, tutor sudah terbiasa melaksanakan proses tutoring serta siswa lain menjadi lebih berani bertanya apabila masih terdapat materi yang kurang jelas karena yang menjelaskan adalah teman sebayanya. Menurut Arya (2010), melalui pembiasaan atau metode drill akan muncul perilaku yang semakin kuat bila diberikan penguatan (reinforcement). Seseorang akan terlihat mudah melakukan sesuatu apabila terbiasa. Proses pembelajaran tersebut sejalan dengan hasil observasi guru pada siklus 2 menunjukkan bahwa pelaksanaan pelaksanaan pembelajaran sesuai dengan standar proses, pembelajaran sesuai dengan metode tutor sebaya, serta pengelolaan kelas yang berada dalam kategori sangat baik. Pada aspek penguasaan materi, peneliti mendapatkan point maksimal yaitu $100 \%$.

Berdasarkan hasil penelitian di atas, dapat disimpulkan bahwa metode metode tutor sebaya dapat meningkatkan hasil belajar matematika dan motivasi belajar siswa terhadap pelajaran matematika. Hasil penelitian ini membuktikan bahwa pentingnya pemilihan metode pembelajaran yang tepat dalam melaksanakan kegiatan belajar mengajar dapat menghasilkan hasil yang optimal. Hal ini sejalan dengan hasil penelitian 
lainnya seperti penelitian yang telah dilaksanakan oleh Septiana (2013) dan Wulandari (2010) yang menunjukkan bahwa metode tutor sebaya dapat meningkatkan hasil belajar matematika siswa. Serta penelitian yang dilakukan oleh Suprihatin (2015) dan Ritaningsih (2017) yang menunjukkan bahwa metode tutor sebaya bisa meningkatkan motivasi belajar siswa. Berdasarkan hasil penelitian tersebut, dengan menerapkan metode tutor sebaya dapat meningkatkan hasil belajar dan motivasi belajar siswa dalam pembelajaran matematika.

\section{SIMPULAN DAN SARAN}

Penerapan metode tutor sebaya dapat meningkatkan hasil belajar dan motivasi belajar siswa kelas XI MIPA 4 SMA Negeri 1 Ambarawa. Berdasarkan hasil tersebut maka disarankan bagi guru untuk menerapkan metode tutor sebaya sebagai salah satu cara untuk mengoptimalkan peran peserta didik sebagai subjek dan bukan sekedar objek belajar. Pembelajaran seperti ini juga memberikan kesempatan kepada peserta didik untuk saling berinteraksi dalam proses belajar. Selain itu, pembelajaran menggunakan metode tutor sebaya dapat menerapkan prinsip belajar dari berbagai sumber serta mewujudkan prinsip bahwa siswa pun bisa bertindak sebagai "guru" bagi teman-teman yang lain.

\section{DAFTAR PUSTAKA}

Arikunto, Suharsimi. 2002. Prosedur Penelitian Suatu Pendekatan Praktek. Jakarta: Rineka Cipta.

Arikunto, S., Suhardjono., dan Supardi. 2009. Penelitian Tindakan Kelas. Jakarta : PT Bumi Aksara

Arya. 2010. Teori belajar Behaviorisme. Diakses melalui http://belajarpsikologi.com/teori-belajar-behaviorisme/html pada 9 Mei 2019.

Djamarah, Syaiful Bahri. 2002. Strategi Belajar Mengajar. Jakarta : PT. Rineka Cipta.

Hanafiah, N., dan Suhana C. 2010. Konsep Srategi Pembelajaran. Bandung : PT Refika Aditama

Hendriana, Heris. 2017. Hardskills dan Softskills matematik siswa. Bandung: Rifeka Aditama.

Khasanah, Ummi. 2013. Peningkatan Motivasi Belajar IPS Melalui Metode Tutor Sebaya pada Siswa Kelas II SD Negeri 01 Mojogedang Kecamatan Mojogedang Kabupaten Karanganyar Tahun Pelajaran 2012/2013.

Mawarni, E., Mulyani, B., \& Yamtinah, S. (2014). Penerapan Peer Tutoring Dilengkapi Animasi Macromedia Flash Dan Handout Untuk Meningkatkan Motivasi Berprestasi Dan Prestasi Belajar Siswa Kelas XI IPA 4 SMAN 6 Surakarta Tahun Pelajaran 2013/2014 Pada Materi Kelarutan Dan Hasil Kali Kelarutan. Jurnal Pendidikan Kimia, 4(1), 29-37. Diperoleh dari jurnal.fkip.uns.ac.id/index.php/ kimia/article/view/4883 
Menteri Pendidikan. 2016. Peraturan Menteri Pendidikan dan Kebudayaan Republik Indonesia Nomor 8 Tahun 2009 Tentang Standar Proses Pendidikan Dasar dan Menengah. Jakarta: Direktorat Jendral Pendidikan Dasar dan Menengah.

Menteri Pendidikan. 2016. Peraturan Menteri Pendidikan dan Kebudayaan Republik Indonesia Nomor 22 Tahun 2016 Tentang Standar Proses Pendidikan Dasar dan Menengah. Jakarta: Direktorat Jendral Pendidikan Dasar dan Menengah.

Prasojo, Teguh. 2016. Peningkatan Aktivitas dan Hasil Belajar Matematika dengan Metode Tutor Sebaya pada Siswa Kelas XIPA 7 Materi Trigonometri SMA Negeri $1 \quad K u d u s . \quad$ Diperoleh dari https://journal.unnes.ac.id/nju/index.php/kreano/article/view/5049

Ritaningsih. 2017. Upaya Peningkatan Motivasi dan Hasil Belajar Siswa Melalui Kegiatan Metode Tutor Sebaya dalam Pengajaran Remedial Materi Getaran dan Gelombang di Kelas VIII C Semester Genap Tahun Pelajaran 2015/2016 SMP Negeri 1 Pangkah Kabupaten Tegal. Diperoleh dari https://www.researchgate.net/publication/318422186 _UPAYA_MENINGKATKAN_MOTIVASI_DAN_HASIL_BELAJAR_SISWA - MELALÜI KEGIATAN TUTOR SEBAYA DĀLAM PENGAJARAN REM EDIAL_MATERI_GETARAN_DAN̄_GELOMBANG_DI_KELAS_VIII_C_SE MESTER_GENAP_TAHUN_PELAJARAN_20152016_SMPPNEG

Sabaruddin. 2009. Peranan Metode Tutor Sebaya Dalam Meningkatkan Hasil Belajar Siswa Kelas 5 Sdn Inpres Karawa Kab. Pinrang Pada Pokok Bahasan KPK dan $F P B$. UPP PGSD Pare Pare. Makasar. Diperoleh dari http://digilib.uinsuka.ac.id/14199/2/

Sardiman, A. M. 2014. Interaksi \& Motivasi Belajar Mengajar. Jakarta : PT Raja Grafindo Persada.

Tampubolon, S. M. 2014. Penelitian Tindakan Kelas Sebagai Pengembangan Profesi Pendidik Keilmuan. Jakarta : PT Gelora Akasara Pratama.

Sardiman, A.M. (2005). Interaksi dan Motivasi Belajar Mengajar. Jakarta: Rajawali Press.

Septiana, I Putu D. W. 2013. Meningkatkan Hasil Belajar Siswa Pada Mata Pelajaran Matematika Melalui Metode Tutor Sebaya Materi Bangun Datar Kelas VII C SMP Kristen 2 Salatiga. Fakultas Keguruan dan Ilmu Pendidikan. Universitas Kristen Satya Wacana. Salatiga.

Suherman, dkk. 1992. Strategi Belajar Mengajar Matematika. Jakarta : Universitas Terbuka, Departemen Pendidikan Dan Kebudayaan.

Suprihatin, Siti. 2015. Upaya Guru Dalam Meningkatkan Motivasi Belajar Siswa. Pendidikan Ekonomi. Universitas Muhammadiyah Metro. Lampung. Diperoleh dari http://ojs.fkip.ummetro.ac.id/index.php/ekonomi/article/view/144/0

Uno, Hamzah B. (2011). Teori Motivasi dan Pengukurannya. Jakarta : Bumi Aksara.

Wulandari, Fitri. 2010. Aplikasi Metode Tutor Sebaya Pada Materi Teorema Pythagoras Untuk Siswa Kelas VIII SMP N 10 Salatiga. Fakultas Keguruan dan Ilmu Pendidikan. Universitas Kristen Satya Wacana. Salatiga. 